\title{
Intramuscular Dexmedetomidine as Premedication for General Anaesthesia in Patients Undergoing Laparoscopic Cholecystectomy - A Comparative Study
}

\author{
Anindya Kishore Debnath ${ }^{1}$, Anjana Bose Ghosh Dastidar ${ }^{2}$ \\ 1RMO-Cum-Clinical Tutor, Department of Anaesthesiology and Critical Care, RG Kar Medical College, Kolkata, \\ West Bengal, India. ${ }^{2}$ Associate Professor, Department of Anaesthesiology, Diamond Harbour Government Medical \\ College, Harindanga, West Bengal, India.
}

\section{ABSTRACT}

\section{BACKGROUND}

The efficacy of Intramuscular Dexmedetomidine, as premedication, in obtunding the hemodynamic responses during laryngoscopy, endotracheal intubation and pneumoperitoneum and also the peroperative and postoperative analgesic and anaesthetic requirement in patients undergoing laparoscopic cholecystectomy was studied.

\section{METHODS}

Study arm (Gr- D n=30) received Inj. Dexmedetomidine- $2 \mu \mathrm{g} / \mathrm{Kg}(1.5 \mathrm{ml}$. average) $\mathrm{IM}$ and control arm (Gr- $\mathrm{R} \mathrm{n}=30$ ) received Inj. Ranitidine HCL- $1.5 \mathrm{ml}$ IM 1 hour before induction. Premedication with inj. Glycopyrrolate- $4 \mu \mathrm{g} / \mathrm{Kg}$, Fentanyl Citrate $2.0 \mu \mathrm{g} / \mathrm{Kg} \&$ inj. Ondansetron- $4 \mathrm{mg}$ I V, induced with Inj. Propofol- $2 \mathrm{mg} / \mathrm{Kg}$ and intubated with Inj. Atracurium Besylate- $0.5 \mathrm{mg} / \mathrm{Kg}$. Anaesthesia was maintained with $\mathrm{N}_{2} \mathrm{O}, \mathrm{O}_{2}$ \& Sevoflurane. Dose of Sevoflurane was increased if signs of light anaesthesia occurred, if signs persisted then repeat dose Fentanyl was given. Sevoflurane conc. was decreased if hypotension occurred and if persisted then phenylephrine was given. Bradycardia was treated with inj. Atropine $0.6 \mathrm{mg}$ I.V. Patient was reversed with Inj. glycopyrrolate and neostigmine. Post-operative heart rate, NIBP, level of sedation, analgesic requirement was monitored for one hour. It is a prospective, double-blind, randomized, placebo-controlled clinical study.

\section{RESULTS}

Heart rate, mean arterial pressure, fentanyl requirement, sevoflurane requirement at different time intervals during operation and post operatively at $60 \mathrm{~min}$. were analysed by pair t-test and was found to be statistically significant between two arms.

\section{CONCLUSIONS}

Inj. Dexmedetomidine $(2 \mu \mathrm{g} / \mathrm{Kg})$ as intramuscular premedication attenuates haemodynamic responses to laryngoscopy, endotracheal intubation \& pneumoperitoneum \& provides significant haemodynamic stability up to one hour postoperatively.

\section{KEY WORDS}

Dexmedetomidine, Intubation, Laparoscopic Surgery, Laryngoscopy,
Corresponding Author: Dr. Anjana Bose Ghosh Dastidar, \#46/2, Bosepukur Road, Canvas Apartment, Flat $1 B$, Kolkata-700042, West Bengal, India. E-mail: anjanag_dastidar@yahoo.co.in

DOI: $10.14260 / \mathrm{jemds} / 2019 / 674$

Financial or Other Competing Interests: None.

How to Cite This Article:

Debnath AK, Dastidar ABG. Intramuscular dexmedetomidine as premedication for general anaesthesia in patients undergoing laparoscopic cholecystectomya comparative study. J. Evolution Med. Dent. Sci. 2019;8(42):3105-3109, DOI: $10.14260 /$ jemds/2019/674

Submission 22-08-2019, Peer Review 01-10-2019, Acceptance 08-10-2019, Published 21-10-2019.

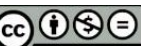

Pneumoperitoneum 


\section{BACKGROUND}

The challenge in anaesthesia is to maintain a balance between the stress of the laryngoscopy, intubation and surgery with the cardio-respiratory depressant effects of deeper levels of anaesthesia. Laryngoscopy and intubation is a strong stimulus for cardiovascular system. ${ }^{[1]}$ Response is greater with increasing force and duration of laryngoscopy.[2] The elevation in arterial pressure typically starts within 5 seconds of laryngoscopy, peaks in 1 to 2 minutes and returns to control level within 5 minutes.[1] It can be prevented by increasing the depth of anaesthesia. Volatile anaesthetic agents, aerosol or application of topical anaesthetics may be beneficial. [3] Large doses of fentanyl $(5-10 \mu \mathrm{g} / \mathrm{Kg})$ may attenuate the response but causes prolonged respiratory depression. Topical anaesthetics, parenteral opioids and beta blockers may be used in combination with narcotics.

Dexmedetomidine, a selective and specific $\alpha_{2}$-adrenergic agonist is beneficial for premedication to reduce sympathetic activity with attenuation of neuroendocrine and haemodynamic responses to surgery and anaesthesia and to decrease anaesthetic and analgesic requirement. Laparoscopic surgeries have multiple benefits compared to open procedures, but it presents several challenges for the anaesthesiologist. [4] The pneumoperitoneum and the patient position required for laparoscopy induces pathophysiologic changes that complicate anaesthetic management. Several drugs and interventions have been tried to reduce complications e.g. use of remifentanil, clonidine, or gasless laparoscopy.[5],[6],[7] In view of these observations the present study was designed to evaluate the efficacy of intramuscular Dexmedetomidine as premedication for blunting the hemodynamic response to laryngoscopy, endotracheal intubation and pneumoperitoneum and dose requirement of intra-operative analgesic and anaesthetic agents in patients undergoing laparoscopic cholecystectomy under general anaesthesia.

\section{METHODS}

The present study was carried out from February 2016 to January 2017 after approval from the Institutional Ethics Committee. Informed consent was obtained from all patients included in the study. $60(n=60)$ patients aged $18-50$ years of ASA-grade 1 and 2 undergoing Laparoscopic Cholecystectomy under General anaesthesia were included in the study. They were divided into two groups-

1. Group D (n-30) received Inj. Dexmedetomidine- $2 \mu \mathrm{g} / \mathrm{Kg}$ (total volume $1.5 \mathrm{ml}$ average) I.M.

2. Group R (n-30) received Ranitidine HCL- 1.5 I.M. as placebo.

Exclusion criteria were patient refusal, known hypersensitivity to the drugs, hypertensives on two drug regime, mental retardation or psychiatric illness and pregnancy.

The patients were brought to the observation room and baseline parameters such as heart rate (HR), blood pressure (systolic (SBP), diastolic (DBP) and mean arterial (MAP)) and oxygen saturation $\left(\mathrm{SpO}_{2}\right)$ were measured. They were then randomly divided into 2 groups with every second patient in the study group.

Patients received Dexmedetomidine or Ranitidine IM 60 minutes before induction of general anaesthesia. The baseline heart rate, blood pressure (systolic, diastolic and mean), oxygen saturation and ECG were monitored.

The level of sedation was assessed by Ramsay Sedation Score (RSS). ${ }^{[8]}$ In both groups before induction, baseline heart rate, blood pressure (systolic, diastolic and mean), oxygen saturation and ECG were recorded. I.V. infusion was started with Ringer's lactate at a rate of $6-8 \mathrm{ml} / \mathrm{Kg} / \mathrm{hr}$. Pre oxygenation with $100 \% \mathrm{O}_{2}$ was started and premedication was given with inj. Glycopyrrolate- $4 \mu \mathrm{g} / \mathrm{Kg}$, inj. Ondansetron$4 \mathrm{mg}$ I.V., inj. fentanyl citrate $2.0 \mu \mathrm{g} / \mathrm{Kg}$ I.V. and Inj. Midazolam- $0.05 \mathrm{mg} / \mathrm{Kg}$ I.V. Patients were induced with Inj. Propofol $2 \mathrm{mg} / \mathrm{Kg}$ and intubated with Inj. Atracurium besylate- $0.5 \mathrm{mg} / \mathrm{Kg}$. Anaesthesia was maintained with $70 \%$ $\mathrm{N}_{2} \mathrm{O}$ in $\mathrm{O}_{2}$ and Sevoflurane inhalation. Neuromuscular block was maintained with inj. Atracurium besylate $0.15 \mathrm{mg} / \mathrm{Kg}$. Inj. Paracetamol $1 \mathrm{gm}$ was given intraoperatively. Laparoscopy was performed with the table at a $15^{\circ}$ head-up tilt and intra-abdominal pressure (IAP) was maintained at 10-12 mmHg.

Sevoflurane was administered using the lowest possible end-tidal concentration according to the following scheme: If hypertension (MAP 20\% or more over the baseline values or over $110 \mathrm{mmHg}$ ), tachycardia (HR $20 \%$ or more over the baseline values or over $100 \mathrm{bpm}$ ), or signs of light anaesthesia (sweating, lacrimation, flushing) occurred, administration of Sevoflurane $0.6 \%$ end-tidal concentration was begun. If MAP and/or HR did not decrease to the predetermined level within 4 mins, the end-tidal concentration of Sevoflurane was increased with $0.2 \%$ steps every $4 \mathrm{~min}$ if necessary up to a maximum of $2.0 \%$. If the endtidal Sevoflurane concentration of $2.0 \%$ was not sufficient, inj. Fentanyl was given in $1.0 \mu \mathrm{g} / \mathrm{Kg}$ increments. When BP and HR decreased and were within the predetermined limits, the Sevoflurane concentration was decreased every 4 mins. in $0.2 \%$ steps as long as the values remained within the accepted limits. End-tidal Sevoflurane concentration was measured using an anaesthetic agent monitor. The overall mean end-tidal concentration of Sevoflurane during laparoscopy was assessed. If hypotension (MAP 20\% or more below the baseline value or below $70 \mathrm{mmHg}$ ) occurred, Sevoflurane concentration was first reduced with $0.2 \%$ steps every $4 \mathrm{~min}$. If MAP remained below the predetermined limits even after discontinuation of Sevoflurane, ringer's lactate solution $250 \mathrm{~mL}$ was given over a 5-min period, if hypotension persisted it was treated with inj. Phenylephrine $50 \mu \mathrm{g}$ I.V. bolus dose.

Bradycardia, i.e. HR less than 50 per minute lasting more than $1 \mathrm{~min}$, was treated with inj. atropine $0.6 \mathrm{mg}$ I.V.

Sevoflurane was discontinued at the start of laparoscopy port closure. After completion of surgery neuromuscular block was reversed with Inj. glycopyrrolate $0.01 \mathrm{mg} / \mathrm{Kg}$ and Inj. neostigmine $0.05 \mathrm{mg} / \mathrm{Kg}$ and patient was extubated when adequate spontaneous ventilation was established. All the patients were shifted to PACU for post-surgical recording of parameters (heart rate and NIBP at 30 mins. and 60 mins. after recovery, level of sedation at $60 \mathrm{mins}$, analgesic requirement and side effects if any noted up to $60 \mathrm{mins}$ ). In PACU all patients received moist $\mathrm{O}_{2}$ inhalation for 2 hours. 
Rescue analgesic was administered on patients demand or when the VAS score $\geq 4$ whichever earlier, in the form of inj. Tramadol $3 \mathrm{mg} / \mathrm{Kg}$ I.V. over 30 mins. diluted in $50 \mathrm{ml}$ NS. The time of first rescue analgesic was noted.

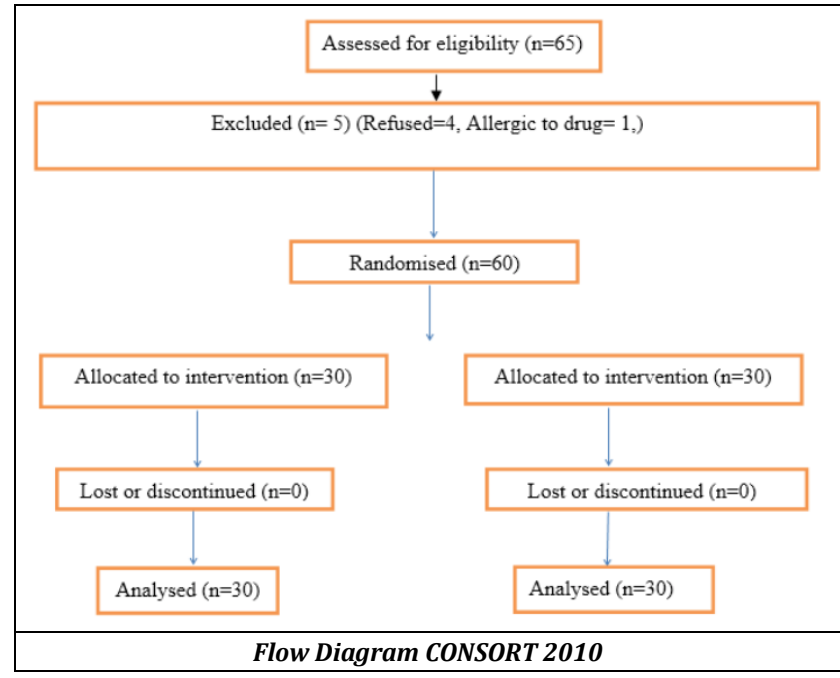

\section{Statistical Analysis}

Data have been summarized by Descriptive Statistics. Numerical variables have been compared between groups by unpaired t-test. Categorical variables have been compared between groups by Chi square test. All analyses were 2-tailed and $\mathrm{p}<0.05$ was considered statistically significant. The primary variable of our study was to detect a $10-15 \%$ difference in hemodynamic parameters between the groups with $80 \%$ statistical power and a significance level $(\alpha)$ of 0.05 (two-tailed) and we calculated a sample size of 60 patients by using the software Statistica Version 6 ( Tulsa, Oklahoma: StatSoft Inc.,2001).

\section{RESULTS}

The demographic parameters were comparable among the two groups.The 2-tailed unpaired t-test was applied. The difference of mean heart rate before induction and after 1 min and 5 mins following laryngoscopy and intubation was statistically highly significant in the two groups $(p=0.000$, $p=0.000, p=0.000$ respectively). The difference persisted after pneumoperitoneum, after change of patient position and 15 mins after pneumoperitoneum; 30 mins., after pneumoperitoneum the difference was not significant $(p=0$. 154) and 5 mins. After release of pneumoperitoneum difference was significant (Table 1). Statistically significant difference $(\mathrm{p}<0.05)$ was found at 30 mins. And 60 mins., of post-operative period and the mean HR was lower in Group D (table 1).

Applying the 2-tailed unpaired t-test (assuming equal variances) between the mean of MAP of each group $p<0.05$ was found at before induction, during $1 \mathrm{~min}$ and $5 \mathrm{mins}$ following laryngoscopy and intubation, after pneumoperitoneum, after change of patient position, 15 mins., and 30 mins., after pneumoperitoneum and 5 mins., after release of pneumoperitoneum and $p>0.05$ was found before premedication. Hence baseline MAP was comparable among the groups and statistically significant difference is found at most of the time in mean MAP between the two groups before induction, during laryngoscopy and intubation, during pneumoperitoneum and even after release of pneumoperitoneum. (table 2). Statistically significant difference was found at 30 mins Group R- 93.0 \pm 6.731 and Group D- $84.5 \pm 4.883$ and at 60 mins. Group R-95.7 \pm 6.747 and Group D-86.6 \pm 3.838 of post-operative period and the mean MAP is significantly lower in Group D (table 2).

The total Fentanyl requirement $(\mu \mathrm{g} / \mathrm{Kg})$ and the mean end-tidal Sevoflurane requirement during surgery among the groups are statistically significant. There is reduction in Fentanyl requirement in Group D. Group P: Group D 3.63 $\pm 0.718: 2.83 \pm 0.592$ (table 3 ) and also reduction in endtidal Sevoflurane requirement in Group D. (table 3).

\begin{tabular}{|c|c|c|c|c|}
\hline$\frac{\mathscr{y}}{\frac{\tilde{d}}{\tilde{J}}}$ & 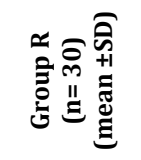 & 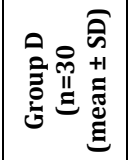 & 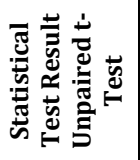 & 苞 \\
\hline $\begin{array}{l}\text { Baseline/Before } \\
\text { pre-medication }\end{array}$ & $81.3 \pm 8.188$ & $80.3 \pm 6.450$ & $p=0.601$ & $\begin{array}{c}\text { Not } \\
\text { significant }\end{array}$ \\
\hline $\begin{array}{c}\text { Before } \\
\text { induction }\end{array}$ & $93.5 \pm 4.754$ & $62.3 \pm 9.411$ & $\mathrm{p}=0.000$ & significant \\
\hline $\begin{array}{c}1 \text { minute after } \\
\text { laryngoscopy \& intubation }\end{array}$ & $110.8 \pm 5.222$ & $80.6 \pm 5.899$ & $\mathrm{p}=0.000$ & significant \\
\hline $\begin{array}{c}5 \text { minutes after } \\
\text { laryngoscopy \& intubation }\end{array}$ & $89.3 \pm 6.369$ & $68.0 \pm 7.502$ & $\mathrm{p}=0.000$ & significant \\
\hline $\begin{array}{c}\text { After } \\
\text { pneumoperitoneum }\end{array}$ & $87.5 \pm 5.685$ & $77.1 \pm 7.508$ & $\mathrm{p}=0.000$ & significant \\
\hline $\begin{array}{l}\text { After change } \\
\text { of position }\end{array}$ & $89.1 \pm 3.652$ & $78.0 \pm 11.371$ & $\mathrm{p}=0.000$ & significant \\
\hline $\begin{array}{l}15 \text { minutes after } \\
\text { pneumoperitoneum }\end{array}$ & $87.0 \pm 5.003$ & $76.1 \pm 20.481$ & $p=0.006$ & significant \\
\hline $\begin{array}{c}30 \text { minutes after } \\
\text { pneumoperitoneum }\end{array}$ & $80.6 \pm 6.688$ & $75.8 \pm 16.914$ & $\mathrm{p}=0.154$ & $\begin{array}{c}\text { Not } \\
\text { significant }\end{array}$ \\
\hline $\begin{array}{l}5 \text { minutes after } \\
\text { pneumo release }\end{array}$ & $82.3 \pm 6.188$ & $75.5 \pm 4.462$ & $\mathrm{p}=0.000$ & significant \\
\hline $\begin{array}{l}30 \mathrm{~min} \\
\text { post op }\end{array}$ & $85.1 \pm 8.755$ & $67.2 \pm 9.331$ & \multirow{2}{*}{$\begin{array}{l}p=0.000 \\
p=0.000\end{array}$} & \multirow{2}{*}{$\begin{array}{l}\text { highly } \\
\text { significant }\end{array}$} \\
\hline $\begin{array}{l}60 \mathrm{~min} \\
\text { post op }\end{array}$ & $88.4 \pm 9.489$ & $71.4 \pm 2.372$ & & \\
\hline Table 1. Comp & $\pi$ & 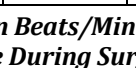 & 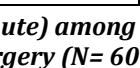 & Wu \\
\hline
\end{tabular}

\begin{tabular}{|c|c|c|c|c|}
\hline$\frac{\sqrt[3]{\frac{\pi}{3}}}{\frac{3}{2}}$ & 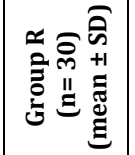 & 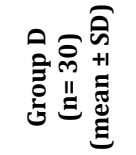 & 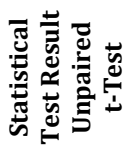 & 总 \\
\hline $\begin{array}{l}\text { Baseline/ Before } \\
\text { pre-medication }\end{array}$ & $90.5 \pm 6.174$ & $88.4 \pm 5.028$ & $\mathrm{p}=0.154$ & $\begin{array}{c}\text { Not } \\
\text { significant }\end{array}$ \\
\hline $\begin{array}{c}\text { Before } \\
\text { induction }\end{array}$ & $89.5 \pm 5.131$ & $74.6 \pm 4.461$ & $\mathrm{p}=0.000$ & significant \\
\hline $\begin{array}{c}1 \text { minute after } \\
\text { laryngoscopy \& intubation }\end{array}$ & $\begin{array}{c}111.8 \\
\pm 5.222 \\
\end{array}$ & $94.1 \pm 4.604$ & $\mathrm{p}=0.000$ & significant \\
\hline $\begin{array}{c}5 \text { minutes after } \\
\text { laryngoscopy \& intubation }\end{array}$ & $91.4 \pm 5.969$ & $78.9 \pm 3.418$ & $\mathrm{p}=0.000$ & significant \\
\hline $\begin{array}{c}\text { After } \\
\text { pneumoperitoneum }\end{array}$ & $97.6 \pm 5.424$ & $91.3 \pm 5.609$ & $\mathrm{p}=0.000$ & significant \\
\hline $\begin{array}{c}\text { After change } \\
\text { of position }\end{array}$ & $98.2 \pm 5.020$ & $90.3 \pm 7.530$ & $\mathrm{p}=0.000$ & significant \\
\hline $\begin{array}{c}15 \text { minutes after } \\
\text { pneumoperitoneum }\end{array}$ & $\begin{array}{c}102.7 \\
\pm 5.266 \\
\end{array}$ & $92.4 \pm 6.306$ & $\mathrm{p}=0.000$ & significant \\
\hline $\begin{array}{c}30 \text { minutes after } \\
\text { pneumoperitoneum }\end{array}$ & $103.7 \pm 5.344$ & $91.8 \pm 6.283$ & $\mathrm{p}=0.000$ & significant \\
\hline $\begin{array}{l}5 \text { minutes after } \\
\text { release of pneumo. }\end{array}$ & $92.3 \pm 6.929$ & $84.1 \pm 3.652$ & $\mathrm{p}=0.000$ & significant \\
\hline 30 minutes postoperative & $93.0 \pm 6.731$ & $84.5 \pm 4.883$ & $\mathrm{p}=0.000$ & $\begin{array}{c}\text { highly } \\
\text { significant }\end{array}$ \\
\hline 60 minutes postoperative & $95.7 \pm 6.747$ & $86.6 \pm 3.838$ & $\mathrm{p}=0.000$ & $\begin{array}{c}\text { highly } \\
\text { significant }\end{array}$ \\
\hline \multicolumn{5}{|c|}{$\begin{array}{l}\text { Table 2. Comparing Mean Arterial Pressures ( } \mathrm{mmHg} \text { ) among the } \\
\text { Study Groups at Specified Time Periods during Surgery and Postop. } \\
\text { (N=60) Original }\end{array}$} \\
\hline
\end{tabular}




\begin{tabular}{|c|c|c|c|c|}
\hline $\begin{array}{l}\frac{0}{0} \\
\frac{\pi}{3} \\
\stackrel{3}{3}\end{array}$ & 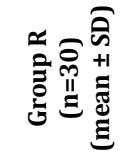 & 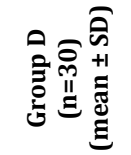 & 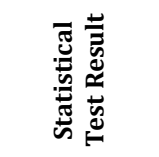 & 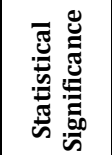 \\
\hline $\begin{array}{c}\text { Total fentanyl } \\
\text { requirement }\end{array}$ & $3.63 \pm 0.718$ & $2.83 \pm 0.592$ & $\begin{array}{l}\text { Unpaired t-test } \\
\mathrm{p}=0.000\end{array}$ & \begin{tabular}{|c|} 
Highly \\
significant
\end{tabular} \\
\hline $\begin{array}{c}\text { Mean end-tidal } \\
\text { isoflurane requirement }\end{array}$ & $0.440 \pm 0.675$ & $0.240 \pm 0.675$ & $\begin{array}{l}\text { Unpaired t-test } \\
\text { p }=0.000\end{array}$ & $\begin{array}{c}\text { Highly } \\
\text { significant }\end{array}$ \\
\hline
\end{tabular}

\begin{tabular}{|c|c|c|c|c|}
\hline & Group R & Group D & Statistical Test Result & \\
\hline Bradycardia & $0(0 \%)$ & $8(26 \%)$ & Chi square test $\mathrm{p}=0.00$ & highly significant \\
\hline \multicolumn{5}{|c|}{ Level of Sedation } \\
\hline Score 1 & $21(70 \%)$ & 0 & Chi square test & highly significant \\
\hline & & & $\mathrm{p}=0.00$ (For all 3 readings) & \\
\hline Score 2 & $9(30 \%)$ & $25(83.3 \%)$ & & \\
\hline Score 3 & 0 & $5(16.7 \%)$ & \\
\hline \multicolumn{6}{|c|}{ Table 4. Comparing Adverse Effects During Surgery among the } \\
Groups (N=60), Bradycardia and Sedation-Original \\
\hline
\end{tabular}

\begin{tabular}{|c|c|c|c|c|}
\hline Variable & $\begin{array}{c}\begin{array}{c}\text { Group R } \\
n=30\end{array} \\
\end{array}$ & $\begin{array}{c}\text { Group D } \\
n=30\end{array}$ & $\begin{array}{c}\text { Statistical } \\
\text { Test Result }\end{array}$ & Significan \\
\hline \begin{tabular}{|l} 
Rescue an \\
\end{tabular} & $24(80 \%)$ & $8(26.7 \%)$ & \multirow{2}{*}{$\begin{array}{c}\text { Chi square test } \\
\mathrm{p}=0.000\end{array}$} & \multirow{2}{*}{$\begin{array}{c}\text { highly } \\
\text { significant }\end{array}$} \\
\hline No analgesic needed & $6(20 \%)$ & $22(73.3 \%)$ & & \\
\hline
\end{tabular}

Incidence of adverse effect (bradycardia) during surgery is more in Group D on Chi square test. ( $p$ value $=0.000$ ) is highly significant (table 4). The level of sedation at 60 mins of post-operative period was evaluated according to Ramsay Sedation Score and the patients of Group D were found to be more sedated. The incidence of adverse effects (bradycardia) up to 60 mins., of post-operative period between the groups was significant and the incidence was more in Group D $5(16.6 \%)$ and $0(0 \%)$ for Group $P$, so Chi square test. ( $\mathrm{p}$ value $=0.000$ ).

Statistically significant difference in need for rescue analgesic upto 60 mins., of post-operative period between the groups was noted and the patients in Group D required less rescue analgesic. Table-5.

\section{DISCUSSION}

Our study showed that inj. Dexmedetomidine $2 \mu \mathrm{g} / \mathrm{Kg}$ I.M. as premedication 60 minutes before induction blunted the hemodynamic response to laryngoscopy and endotracheal intubation compared to placebo. It also attenuated the haemodynamic changes during peritoneum insufflation in laparoscopic surgery.

Sulaiman S et al, Aksu R et al, Ghodki PS et al, in different studies also observed that Inj. Dexmedetomidine, as premedication attenuated cardiovascular responses to laryngoscopy and tracheal intubation.[9,10,11] D. P. Bhattacharjee et al observed that in patients undergoing elective laparoscopic cholecystectomy with Dexmedetomidine intravenous infusion the mean arterial pressure and heart rate were significantly less after intubation and pneumoperitoneum.[12]

Heart rate increased in Group $\mathrm{R}$ after pneumoperitoneum, after change of patient position till 15 mins after pneumoperitoneum, it reduced to near baseline at $30 \mathrm{mins}$ of pneumoperitoneum and 5 mins after release of pneumoperitoneum. In Group D the heart rate did not change much from the baseline values at any stage.

Mean arterial pressure (MAP) increased in Group R after pneumoperitoneum and increased further at 15 mins and 30 mins of pneumoperitoneum. The MAP decreased after 5 mins of release of pneumoperitoneum and reached near the baseline values. In Group D the MAP increased slightly after pneumoperitoneum did not change much at 15 mins and 30 mins of pneumoperitoneum and all the values were close to the baseline values. The MAP decreased 5 mins after release of pneumoperitoneum and the mean value was just below the baseline values. The MAP values between the groups have highly significant statistical difference at all stages of pneumoperitoneum including 5 mins after release of pneumoperitoneum $(\mathrm{p}=0.000)$, Ghodki PS et al, found that during laparoscopy MAP and heart rate increase was low in patients receiving dexmedetomidine. Our study results corroborate with this study. [11]

In our study, the mean inj. Fentanyl requirement in Group $\mathrm{R}$ were $3.63 \mu \mathrm{g} / \mathrm{Kg}$ and for Group D were $2.83 \mu \mathrm{g} / \mathrm{Kg}$ respectively. Difference is statistically highly significant between the groups $(\mathrm{p}=0.000)$. Scheinin $\mathrm{H}$ et al, also found that pretreatment with a single I.M. injection of 2.5 microgram $/ \mathrm{Kg}$ Dexmedetomidine is efficient in decreasing the intraoperative fentanyl requirement. [13]

The overall mean end-tidal sevoflurane concentration required during surgery to maintain the pre-defined anaesthesia endpoints in Group R was $0.44 \%$ and in Group D it was $0.24 \%$ and on statistical analysis there is highly significant difference between the groups.

V. M. Keniya et al (2011) and Bajwa et al studied sixty patients scheduled for elective surgery who received isoflurane-opioid-dexmedetomidine anaesthesia and found that the need for thiopentone, fentanyl and isoflurane was decreased. [14,15] Ghodki PS et al observed that dexmedetomidine as an anaesthetic adjuvant in laparoscopic surgery decreased mean Isoflurane concentration requirement during surgery. [11]

The mean post-operative heart rate in Group $\mathrm{R}$ at 30 mins and 60 mins following reversal were 85.1 per min. and 88.4 per min respectively which was higher than baseline values of heart rate in Group D at 30 mins and 60 mins following reversal were 67.2 per min. and 71.4 per min. respectively which was lower than baseline values.

The mean post-operative mean arterial pressure (MAP) in Group $\mathrm{R}$ at 30 and 60 mins following reversal were 93.0 $\mathrm{mmHg}$ and $95.7 \mathrm{mmHg}$ respectively which was higher than baseline values and MAP in Group D at 30 mins and 60 mins were $84.5 \mathrm{mmHg}$ and $86.6 \mathrm{mmHg}$ respectively was lower than baseline values. $80 \%$ of the patients in Group P and $26.7 \%$ patients in Group D, in our study required rescue analgesic within 1 hour following recovery in PACU which was statistically significant $(\mathrm{p}=0.000)$.

When assessed for post-operative level of sedation using Ramsay Sedation Score (RSS) at 60 mins after recovery at post anaesthesia care unit it was found that $70 \%$ patients were anxious or restless (RSS grade 1) and 30\% patients were co-operative and calm (RSS grade 2) in Group R and in Group D 83\% of the patients were calm and co-operative 
(RSS grade 2) and 17\% patients responded to commands only (RSS grade 3$).(p=0.000)$ between the groups on statistical analysis. SR Prasad et al observed that Dexmedetomidine facilitates adequate sedation for mechanical ventilation and also early extubation as compared with Fentanyl. [16,17]

In Group D 8 patients (26.7\%) developed bradycardia during surgery and 5 patients $(16 \%)$ in post anaesthesia care unit all of them responded promptly to inj. Atropine $0.6 \mathrm{mg}$ I.V. This was found to be statistically significant on analysis $(\mathrm{p}=0.000)$. No patients in Group $\mathrm{R}$ developed any other adverse effect requiring intervention. No other adverse effect was observed in Group D. No patients in Group R developed bradycardia or any other adverse effect.

\section{CONCLUSIONS}

Inj. Dexmedetomidine $(2 \mu \mathrm{g} / \mathrm{Kg})$ as intramuscular premedication attenuates haemodynamic responses to laryngoscopy, endotracheal intubation \& pneumoperitoneum compared to placebo \& also provides significant haemodynamic stability up to 60 minutes of post-operative period. It also significantly reduces per-operative analgesic and anaesthetic requirement when used as premedication. Significant bradycardia during surgery \& also during postoperative period is sometimes a needed intervention but there was significant post-operative sedation and decreased analgesic requirement up to 60 minutes.

\section{ACKNOWLEDGEMENT}

All post graduate trainees of Anaesthesiology Department of R. G. Medical College.

\section{REFERENCES}

[1] Henderson J. Airway management in the adult. In: Miller RD, Eriksson LI, Wiener-Kronish JP, et al. eds. Miller's Anaesthesia. $7^{\text {th }}$ edn. Philadelphia: Churchill Livingstone/Elsevier 2010;50:1573-610.

[2] Kanchi M, Nair HC, Banakal S, et al. Haemodynamic response to endotracheal intubation in coronary artery disease: direct versus video laryngoscopy. Indian J Anaesth 2011;55(3):260-5.

[3] Takita K, Morimoto Y, Kemmotsu O. Tracheal lidocaine attenuates the cardiovascular response to endotracheal intubation. Can J Anaesth 2001;48(8):732-6.

[4] Joris JL. Anaesthesia for laparoscopic surgery. In: Miller RD, edr. Text book of Miller's Anaesthesia. $7^{\text {th }}$ edn. Churchill Livingstone/Elsevier Health Sciences 2010;68:2185-202.

[5] Lentschener C, Axler O, Fernandez $H$, et al. Haemodynamic changes and vasopressin release are not consistently associated with carbon dioxide pneumoperitoneum in humans. Acta Anaesthesiol Scand 2001;45(5):527-35.

[6] Das M, Ray M, Mukherjee G. Hemodynamic changes during laparoscopic cholecystectomy: effect of clonidine premedication. IJA 2007;51(3):205-10.

[7] Lindgren L, Koivusalo AM, Kellokumpu I. Conventional pneumoperitoneum compared with abdominal wall lift for laparoscopic cholecystectomy. $\mathrm{Br} \mathrm{J}$ Anaesth 1995;75(5):567-72.

[8] Ramsay MA. Measuring level of sedation in the intensive care unit. JAMA 2000;284(4):441-2.

[9] Sulaiman S, Karthekeyan RB, Vakamudi M, et al. The effects of dexmedetomidine on attenuation of stress response to endotracheal intubation in patients undergoing elective off-pump coronary artery bypass grafting. Annals of Cardiac Anaesthesia 2012;15(1):3943.

[10] Aksu R, Akin A, Bicer C, et al. Comparison of the effects of dexmedetomidine versus fentanyl on airway reflexes and hemodynamic responses to tracheal extubation during rhinoplasty: a double-blind, randomized, controlled study. Current Therapeutic Research Clin Exp 2009;70(3):209-20.

[11] Ghodki PS, Thombre SK, Sardesai SP, et al. Dexmedetomidine as an anaesthetic adjuvant in laparoscopic surgery: an observational study using entropy monitoring. Journal of Anaesthesiology Clinical Pharmacology 2012;28(3):334-8.

[12] Bhattacharjee DP, Nayek SK, Dawn S, et al. Effects of dexmedetomidine on haemodynamics in patients undergoing laparoscopic cholecystectomy- a comparative study. J Anaesth Clin Pharmacol 2010;26(1):45-8.

[13] Scheinin H, Jaakola ML, Sjövall S, et al. Intramuscular dexmedetomidine as premedication for general anaesthesia-a comparative multicenter study. Anaesthesiology 1993;78(6):1065-75.

[14] Keniya VM, Ladi S, Naphade R. Dexmedetomidine attenuates sympathoadrenal response to tracheal intubation \& reduces perioperative anaesthetic requirement. Indian J of Anaesthesia 2011;55(4):352-7.

[15] Bajwa SJS, Kaur J, Singh A, et al. Attenuation of pressor response and dose sparing of opioids and anaesthetics with pre-operative dexmedetomidine. Indian J Anaesth 2012;56(2):123-8.

[16] Prasad SR, Simha PP, Jagadeesh AM. Comparative study between dexmedetomidine and fentanyl for sedation during mechanical ventilation in postoperative paediatric cardiac surgical patients. Indian $\mathrm{J}$ of Anaesthesia 2012;56(6):547-52.

[17] Patel CR, Engineer SR, Shah BJ, et al. Effect of intravenous infusion of dexmedetomidine on perioperative haemodynamic changes and postoperative recovery: a study with entropy analysis. Indian J Anaesth 2012;56(6):542-6. 